\title{
ANALYSIS OF SOCIAL CAPITAL IN ISLAMIC MICROFINANCE
}

\author{
Ahmad Ma'ruf \\ University of Muhammadiyah Yogyakarta \\ macrov_jogja@yahoo.com \\ Widhia Restiawati \\ Researcher for Institute of Public Policy and Economics Study \\ widhia23@gmail.com
}

\begin{abstract}
This study aims to analyze the social capital in the form of trust, social networks, and norms in Islamic Microfinance, with case study in several BMTs in Yogyakarta. In this study, sample of respondents are selected using purposive sampling. This study used a qualitative method with descriptive statistical analysis. Based on the analysis, the result is BMT has succeeded a good record on doing the social capital and trust has the highest value compared to norms and social networks. Trust becomes the most social capital variables that is widely applied in BMT. While norms become the variable that have smallest value of social capital.
\end{abstract}

Keywords: Social Capital, Trust, Social Networks, Norms, Islamic Microfinance.

\begin{abstract}
Abstrak
Penelitian ini bertujuan untuk menganalisis modal sosial dalam bentuk kepercayaan, jaringan sosial, dan norma-norma pada Lembaga Keuangan Mikro Syariah, dengan studi kasus pada beberapa Baitul Maal wa Tamwil (BMT) di Yogyakarta. Dalam penelitian ini, responden dipilih menggunakan purposive random sampling. Penelitian ini menggunakan metode kualitatif dengan analisis statistik deskriptif. Berdasarkan hasil analisis, diperoleh bahwa BMT yang berkinerja bagus memiliki modal sosial yang kuat, dimana aspek kepercayaan merupakan modal sosial tertinggi dibandingkan dengan norma-norma ataupun jaringan sosial. Kepercayaan menjadi variabel modal sosial paling yang utama dikembangkan oleb BMT. Sementara itu, norma menjadi variabel modal sosial yang memiliki nilai terkecil.
\end{abstract}

Kata Kunci: Modal Sosial, Kepercayaan, Jaringan Sosial, Norma, Keuangan Mikro Syariah.

Permalink/DOI: http://dx.doi.org/10.18326/infsl3.v10i1.25-46 


\section{Introduction}

The presence of sharia cooperatives or better known as BMT (Baitul Maal Waa Tamwil) exist in order to respond complicated problems faced by the community. BMT is an Islamic microfinance institution that have direct contact with people in rural area, so the existence is to help people especially poor people in obtaining funds. People categorized unbankable currently can access the financial institution through BMT.

Baitul Maal Waa Tamwil consists of two terms, there are Baitul Maal and Baitul Tamwil. Baitul Maal more directed to efforts collection and distribution of non-profit funds, such as zakat, infaq and shodaqoh. Baitul Tamwil as a collection of business and commercial distribution of funds. The effort has become an integral part of Baitul Maal Waa Tamwil as agency support economic activities of small communities on the basis of Sharia (Sholahuddin, 2006).

Development of Islamic Microfinance Institutions (LKMS) in Indonesia has increased significantly and has a very important role in the development of Indonesian economy. Islamic Financial Services Cooperatives (KJKS) in the form of Baitul Maal Waa Tamwil (BMT) developed very significant.

This is not separated from the development of performance BMT nationally in 2015 has reached Rp 4.7 trillion of assets and the amount of financing about Rp 3.6 trillion. And also in 10 years, there are 561 BMT with legal status cooperative, and has assets of Rp 11.9 trillion and has a membership of 2,694,013 people spread throughout Indonesia (Minister of Cooperatives and SMEs, 2015).

BMT grow rapidly because of the increase in performance throughout the year and also the system adopted very helpful in community. BMT become Islamic financial institutions with the most numbers rather than other Islamic financial institutions. (Ridwan, 2005).

In fact, efforts to increase the performance of BMT emphasized the presence of financial capital, human capital, natural capital, and technological innovation. These variables have important role in 
increasing the productivity of BMT. Focused of such factors as an input indicator to improve performance of BMT sometimes ignore the social capital variables as inputs are actually a very important role in the economy to increase business productivity and efficiency.

According to Putnam, Leonardi and Nanetti, social capital represents the ffeatures of social organization, such as trust, norms and networks that can improve the efficiency of society by facilitating coordinated actions'. It generally refers to 'trust, concern for one's associates, a willingness to live by norms of one's community and to punish those who do not' (Bowles and Gintis, 2002).

According to Putnam (2002), trust is a form of willingness to take risks in relationships based on feeling confident that the others will do something as expected and will always act in a pattern of action of mutual support, at least the other will not act of self-harm and his group. In societies with widespread trust between people and against the institutions, it is easier to conduct transactions and implement changes. Because trust has a great influence on attitudes towards other human beings and facilitates interaction between people (World Bank, in Göransson and Östergren, 2010).

Social networks are patterns of social exchange and interaction that persist over time (Uphoff, in Postelnicu, 2012). The linkages (i.e. social ties) among members of a network are defined by the economic and sociological literature as those features that give the collectivity cohesiveness and facilitate the pursuit of collective goals.

"Social norms specify what actions are regarded by a set of persons as proper or correct, or improper and incorrect". It seems that norms that exist independently of the formal institutional characteristics of society are a key source of trust and trustworthiness (Keefer and Knack, in Neilsen, 2012).

Reed (2009) found evidence that human capital supported by social capital will give a much larger multiplier effect, than if these two sources are independent. Or social capital become increasingly valuable when human capital is in close relation to environmental organizations. This is what gives another reason for the need of the assessment of human capital and social capital simultaneously. 
Adler and Kwon (in Hossain, D.M, 2013) defined some benefits of social capital: facilitates information; the benefit of 'influence, control and power' that helps people to 'get the things done'; and social capital can ensure solidarity and compliance through 'strong social norms and beliefs, associated with a high degree of closure of the network'.

In Indonesia, social capital still not considered affect the development or the performance of BMT. But many studies have proved that social capital affects the performance of Islamic Micro Financial Institutions (LKMS) and very helpful social relationships among boards and customers.

As research conducted by Supardi (2015), social capital in the form of trust formed personal guarantee so that customers can access the financing in Pandawa Cooperative without material guarantee. Mutual trust between cooperative and members formed a social network that is mutually beneficial. The social network gives the trust to BMT, so BMT can continue to develop, and customers get easy access to get financing in BMT as well. Social relations among them based on the norms prevailing in the surrounding community.

Social capital still unfamiliar in the society, and not many people, especially administrators of BMT know about the concept of social capital, how the role of the community as well as its benefits for them. If the research on social capital does not run, and BMT only oriented on the development of financial capital, human capital, and technological capital it will impact on the development of BMT tend to be same with existing financial institution.

\section{Research Method}

This study used a qualitative method with descriptive statistical analysis, the research gives an overview about certain individuals or groups on the circumstances and symptoms that occur (Koentjaraningrat, in Fitriasari 2015). Qualitative research is research that trying to understand the phenomenon of what is experienced by research subjects holistically and descriptions in the form of words and language, in a naturally specific context and by utilizing a variety 
of natural methods (Prasetyo and Jannah, 2006). Descriptive analysis is used to describe the phenomena, behaviors, or other certain object that aims to describe the state of the social phenomenon, without seeing the relationships that exist. Descriptive data analysis aims to explain the data about the characteristics of respondents.

To avoid the uncertainty which would affect the calculation of bias research results, the questionnaire should be measured the validity and reliability of data so that these studies produce valid and reliable data. Validity is a tool to measure something that is used in one research. A valid instrument shows the tool that is used in order to obtain a valid data than can be used to measure the instrument. Reliability test is performed to determine whether the instrument in this case the questionnaire can be used more than once at least by the same respondents will produce consistent data (Basuki \& Yuliadi, 2014).

Objectives of this research are 37 from 80 BMTs that incorporated in Puskopsyah (Center for Sharia Cooperative) in Special District of Yogyakarta. While data used in this study are primary data and secondary data. Primary data in this study obtained by spreading the questionnaire directly to BMT who acts as respondents in the study. Secondary data in this research is data from Puskopsyah Yogyakarta which contained name and address of BMTs.

\section{Result and Discussion}

To avoid the uncertainty which would affect the calculation of bias research results, the questionnaire should be measured the validity and reliability of data so that these studies produce valid and reliable data. Validity and reliability tests to be performed in this study are as follows. This research use calculation of KMO value to measure the validity of each variable using SPSS 15 . The instrument is valid if the $\mathrm{KMO}$ value is greater than 0,50 (Basuki and Yuliadi, 2014). 
Table 1.

Validity Test: Anti-image Matrices Test and KMO and Bartlett's Test

\begin{tabular}{|c|c|c|c|c|c|c|}
\hline $\begin{array}{c}\text { Validity } \\
\text { test }\end{array}$ & $\begin{array}{l}\text { the trust } \\
\text { aspect }\end{array}$ & values & $\begin{array}{c}\text { the social } \\
\text { network } \\
\text { aspect }\end{array}$ & values & $\begin{array}{c}\text { the norms } \\
\text { aspect }\end{array}$ & values \\
\hline \multirow{5}{*}{$\begin{array}{l}\text { Anti-image } \\
\text { Correlation }\end{array}$} & Trust & $0,696(a)$ & Information & $0,744(a)$ & Condition & $0,551(a)$ \\
\hline & Honesty & 0,695 (a) & Promotion & 0,811 (a) & $\begin{array}{l}\text { Islamic } \\
\text { value }\end{array}$ & $0,611(a)$ \\
\hline & Prospect & 0,707 (a) & Program & 0,749 (a) & $\begin{array}{l}\text { Religion } \\
\text { value }\end{array}$ & $0,630(a)$ \\
\hline & Safety & 0,752 (a) & Families & 0,717 (a) & $\begin{array}{l}\text { Culture } \\
\text { value }\end{array}$ & $0,711(a)$ \\
\hline & Product & 0,783 (a) & Cooperation & $0,766(a)$ & Polite & $0,705(a)$ \\
\hline $\begin{array}{l}\text { Kaiser- } \\
\text { Meyer- } \\
\text { Olkin } \\
\text { Measure of } \\
\text { Sampling } \\
\text { Adequacy }\end{array}$ & & 0,726 & & 0,753 & & 0,753 \\
\hline
\end{tabular}

Sources: primary data, process by SPSS 15, 2015

\section{Trust Variable}

Validity test results on the trust aspect above shows that the value of KMO is 0.726 states that the instrument in this research is valid. Anti-image correlation results in a fairly high correlation to each item, namely 0.696 (Trust), 0.695 (Honesty), 0.707 (Prospect), 0.752 (Safety), and 0.783 (Product). It can be stated that the five items that are used to measure the trust variable are valid.

\section{Social Networks Variable}

Validity test results on the social network aspect above shows that the value of KMO is 0.753 states that the instrument in this study is valid. Anti-image correlation resulted in a fairly high correlation to each item, namely 0.744 (Information), 0.811 (Promotion), 0.749 (Program), 0.717 (Families), and 0.766 (Cooperation). It can be stated that the five items were used to measure the social network variables are valid. 


\section{Norms Variable}

Validity test results on the norms variables above shows that the value of $\mathrm{KMO}$ is 0.632 states that the instrument in this research is valid. Anti-image correlation results in a fairly high correlation to each item, namely 0.551 (Condition), 0.611 (Islamic Value), 0.630 (Religion Value), 0.711 (Culture Value), and 0.705 (Polite). It can be stated that the five items used to measure norms variables are valid.

Table 2.

Reliability Test: Cronbach Alpha Value

\begin{tabular}{|c|c|c|c|c|c|c|}
\hline $\begin{array}{l}\text { Reliability } \\
\text { test }\end{array}$ & $\begin{array}{c}\text { the } \\
\text { trust } \\
\text { aspect }\end{array}$ & values & $\begin{array}{c}\text { the social } \\
\text { network } \\
\text { aspect }\end{array}$ & values & $\begin{array}{l}\text { the } \\
\text { norms } \\
\text { aspect }\end{array}$ & values \\
\hline \multirow{5}{*}{$\begin{array}{l}\text { Cronbachs } \\
\text { Alpha } \\
\text { if Item } \\
\text { Deleted }\end{array}$} & Trust & 0,704 & Information & 0,733 & Condition & 0,736 \\
\hline & Honesty & 0,675 & Promotion & 0,786 & $\begin{array}{l}\text { Islamic } \\
\text { value }\end{array}$ & 0,658 \\
\hline & Prospect & 0,754 & Program & 0,711 & $\begin{array}{l}\text { Religion } \\
\text { value }\end{array}$ & 0,599 \\
\hline & Safety & 0,739 & Families & 0,774 & $\begin{array}{l}\text { Culture } \\
\text { value }\end{array}$ & 0,729 \\
\hline & Product & 0,661 & Cooperation & 0,766 & Polite & 0,728 \\
\hline $\begin{array}{l}\text { Cronbach's } \\
\text { Alpha }\end{array}$ & & 0,753 & & 0,794 & & 0,739 \\
\hline
\end{tabular}

Sources: primary data, process by SPSS 15, 2015

Reliability measurement in principle indicates the extent to which measurements can provide relative results that are no different when performed on the same subject. The higher level of reliability measured in the instrument, the more stable and the more reliable the measurement in measuring a symptom will be. In this test, reliability test is done by using Cronbach Alpha value. Calculation of Cronbach Alpha value of each variables using SPSS 15. The variables are valid if the value of Cronbach's alpha $<\alpha$ (Basuki, 2015). If alpha $>0,90$ means perfect reliability, alpha between 0,70 - 0,90 means high reliability, alpha between 0,50 - 0,70 means moderate reliability and if alpha $<0,50$ means low reliability. 


\section{Trust Variable}

Reliability test results on the trust aspect above shows that coefficient value of Cronbach's Alpha is 0.753 states that instrument in this research is reliable. Cronbach's Alpha value of each item are 0.704 (Trust), 0.675 (honesty), 0.754 (Prospect), 0.739 (Safety), and 0.661 (Product). It can be stated that the five items that are used to measure the trust variable are reliable.

\section{Networks Variable.}

Reliability test results on the social network variables above shows that the Cronbach's Alpha value is 0.794 states that instrument in this research is reliable. Cronbach's Alpha value of each item are 0.733 (Information), 0.786 (Promotion), 0.711 (Program), 0.714 (Families), and 0.766 (Cooperation). It can be stated that the five items were used to measure the social network variables are reliable.

\section{Norms Variable}

Reliability test results on norms variable above shows that the value of Cronbach's Alpha is 0.739 states that instrument in this research is reliable. Cronbach's Alpha value of each item are 0.736 (Condition), 0.658 (Islamic Value), 0.599 (Religion Value), 0,729 (Culture Value), and 0.728 (Polite). It can be stated that the five items were used to measure the norms variable are reliable.

\section{Discussion}

Sharia cooperative growth in Yogyakarta during 2012 is quite significant, which grew for about 19 percent. But most of sharia cooperatives are still engaged in the consumptive sector as much as 70 percent, while 30 percent were engaged in the productive sector. Sharia cooperatives developed quite rapidly, due to various factors including human resources are still young and educated so that they can run good management also supported the use of information technology. 
From 300 BMT recorded in the Department of Industry, Trade, Cooperatives and SMEs Yogyakarta, only 82 BMT become member of Puskopsyah Yogyakarta. Therefore, Puskopsyah try to establish a network of BMT in order to accelerate the development. The plan is there will be a BMT primary in each district or city used as named Puskopsyah. Here are the results of the descriptive analysis of social capital with 37 BMT $(46,3 \%)$ member of Puskopsyah Yogyakarta as respondents.

Table 3.

Statistics Test Result of Social Capital Aspect

\begin{tabular}{lccccc}
\hline \multicolumn{1}{c}{ Indicator } & Mean & Variance & $\begin{array}{c}\text { Std. } \\
\text { Deviation }\end{array}$ & Min & Max \\
\hline Trust & 22,92 & 3,354 & 1,831 & 19 & 25 \\
Social Networks & 22.41 & 4.192 & 2.047 & 16 & 25 \\
Norms & 22.11 & 4.155 & 2,038 & 18 & 25 \\
Total Social & 67.44 & 11.701 & 5.916 & 53 & 75 \\
Capital & & & & \\
\hline
\end{tabular}

Sources: primary data, 2015

From the result above, the mean value has approached to the maximum value. It be concluded that BMT has succeed a good record on doing the social capital. It means the BMT officials have done the social capital in BMT. Kanak and Iiguni (2007) also state that microfinance organizations play a vital role in creating social capital.

\section{Trust Variable}

Based on statistical test, the most number found in mode value of trust variable are 5. Means respondents replied strongly agree in the statement in questionnaire. It can be conclude that boards BMT have done social capital aspect of trust in BMT. 
Table 4.

Statistics Test of Trust Variable

\begin{tabular}{cccccc}
\hline & Trust & Honesty & Prospect & Security & Product \\
\hline N Valid & 37 & 37 & 37 & 37 & 37 \\
Missing & 0 & 0 & 0 & 0 & 0 \\
Mean & 4,65 & 4,68 & 4,73 & 4,43 & 4,43 \\
Median & 5,00 & 5,00 & 5,00 & 4,00 & 4,00 \\
Mode & 5 & 5 & 5 & 4 & 4 \\
\hline \multicolumn{5}{c}{ Sources: primary data, 2015 }
\end{tabular}

There are 5 statements that are included in trust variable, i.e. mutual trust between officials BMT or BMT with customer, honesty of officials BMT, good prospect of BMT in the future, security system of BMT, and variety products of BMT. The Mean of each statements are, 4,65 for mutual trust between BMT officials and members, 4,68 for honesty of members BMT, 4,73 for prospect of BMT, 4,43 for security system, and the last 4,43 for variety product of BMT.

The median value is 5,00 for mutual trust between officials and members, honesty of officials BMT, and prospect of BMT. While median value is 4,00 for security system and variety product of BMT. For the mode, mutual trust between officials and members, honesty of officials BMT, and prospect of BMT the value is 5. While for security system and variety product of BMT the mode value is 4 . And social capital on trust aspect have the biggest value compare to norms and social networks.

"Officials not only have a good mutual trust to officials, but they also have good mutual trust to their members. Because of the trust, the members can access financing without material guarantee. The amount of maximum financing is Rp 5 million" (Agus Susanto, head of BMT Mitra Lohjinawi, December 23, 2015). "Members can access financing without material guarantee. Because of trust is more important than material guarantee. The amount of maximum financing is Rp 1 million" (Dedi Heri Sutendi, head of BMT Elbumi 373, December 28, 2015).

Social capital on trust aspect becomes the most social capital variables that are widely applied by BMT. Members can 
apply financing to BMT without material guarantee but using trust/ personal guarantee.

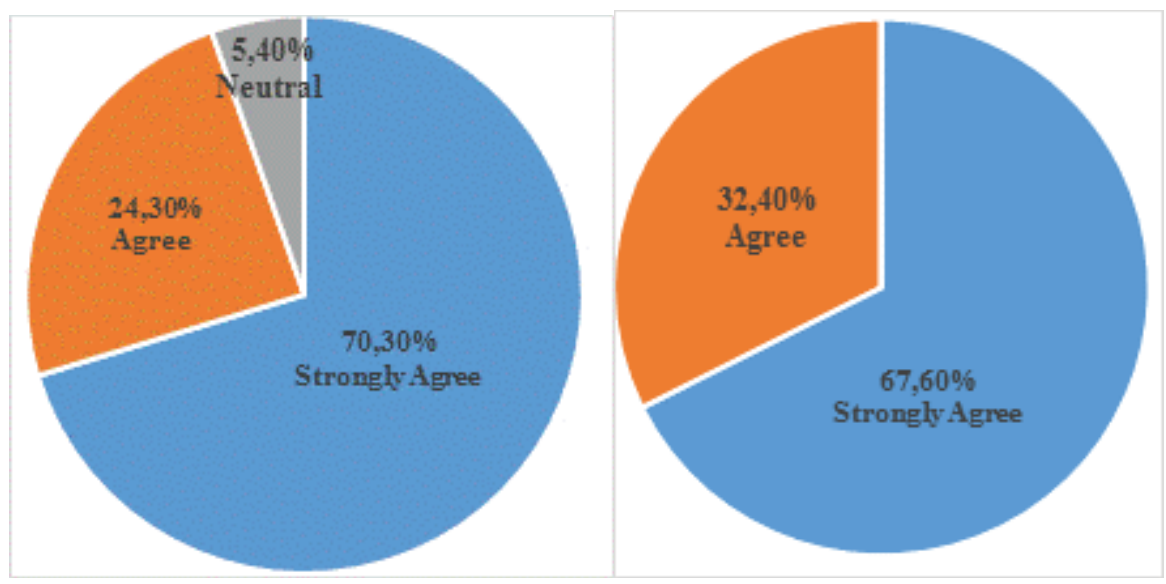

Figure 1.

Perception of Mutual Trust (L) and Perception of Honesty (R)

On first statement in the questionnaire about the "Amanah" or mutual trust between board and members, for about 70.30 percent respondents replied strongly agree. 24.30 percent respondents replied agree, while the other 5.40 percent respondents replied neutral. It can be concluded that most of BMT officials already feel trusted to each other and to members as well. Although there is still a small part of BMT officials who feel the lack of mutual trust among officials and members. The statement is supported by several head of BMT as respondent. On the statement about honesty of BMT officials, figure above shows that respondent replied strongly agree for about 67.60 percent respondents, and 32.40 percent respondents replied agree. Means majority of BMT officials has an excellent level of honesty, and always applied honesty in every aspect of BMT program.

In accordance with Supardi (2015) also prove that social capital on trust aspect, give benefit to the member. They can access financing without material guarantee, but only used personal guarantee (trust). According to Susilo, Triandaru, and Santoso (2000), the main basic of banking activities is confidence (trust), both in terms of raising funds and distributed funds. 
According to Dowla (2006), the success of Grameen bank rests mainly on the creation of social capital (horizontal and vertical networks) establishes a new level of social trust to solve the collective action problems of poor people's access to capital which is important for sustainability of these institutions. Another research also found that trust formed between lender and borrower plays a very important role to make microfinance programme viable (Basargekar, 2010).

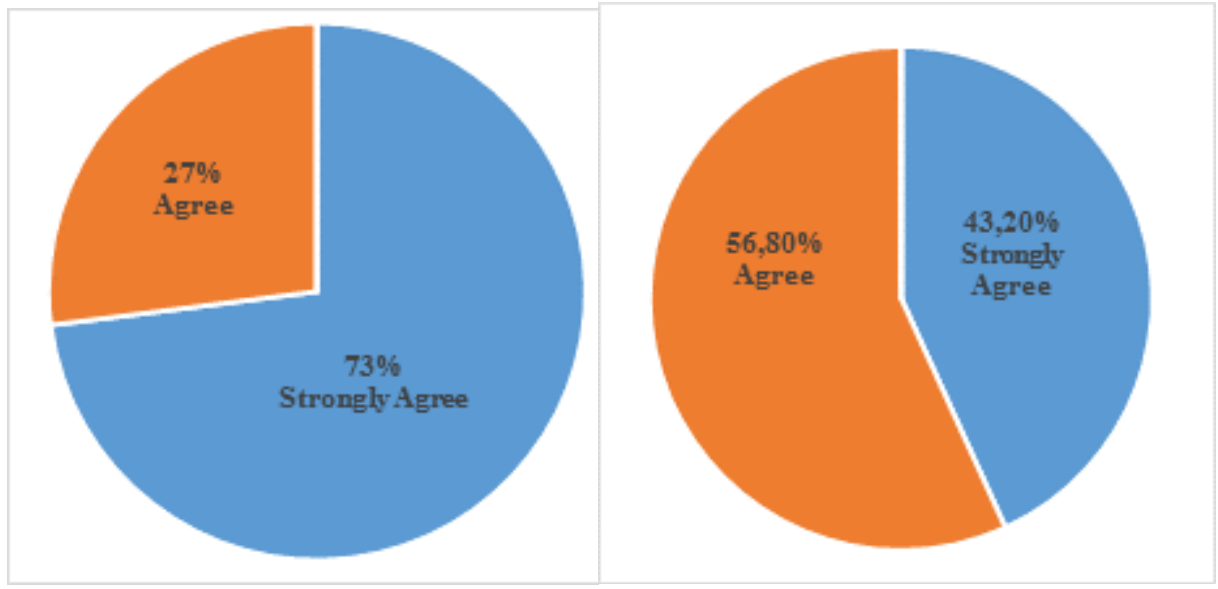

Figure 2.

\section{Perception of BMT Prospect (L) and Perception of Security System (R)}

Statement about prospect BMT in the future, most of respondents strongly agree that BMT will have good prospect ( 73 percent) and 27 percent respondents replied agree that BMT will has good prospect in the future. That is proved by the increasing number of BMT and the value of assets annually. BMT provides many facilities to its members to save money or get financing. So that in the future they are sure that the BMT will continue to grow. BMT boards also believes that BMT will be demand increasingly by rural communities that are not reached by other financial institutions.

Furthermore, the statement about security system owned by BMT, for about 43.20 percent respondents replied strongly agree that BMT has a good security system, while 56.80 percent respondents 
replied agree that BMT has a good security system. Officials believes that BMT has a good level of security, so that the members do not have to worry about their money.

According to Putnam (2002), trust is a form of willingness to take risks in relationships based on feeling confident that the others will do something as expected and will always act in a pattern of action of mutual support, at least the other will not act of self-harm and his group. That's the reason BMT provide financing without material guarantee. The main based is confident and believes that members will not act something that can harm themselves, their group, and BMT.

\section{Social Networks Variable}

Based on statistical test, the most number found in mode value of social networks variable are 5. Means respondents replied strongly agree in the statement in questionnaire. It can be conclude that boards BMT have done social capital aspect of social networks in BMT.

Table 5.

Statistics Test of Social Networks Variable

\begin{tabular}{llllll}
\hline & Information & Promotion & Program & Families & Cooperation \\
\hline N Valid & 37 & 37 & 37 & 37 & 37 \\
Missing & 0 & 0 & 0 & 0 & 0 \\
Mean & 4,41 & 4,51 & 4,38 & 4,51 & 4,59 \\
Median & 4,00 & 5,00 & 4,00 & 5,00 & 5,00 \\
Mode & 4 & 5 & 4 & 5 & 5 \\
\hline
\end{tabular}

Sources: primary data, 2015

There are 5 statements, i.e. information access for members, promotion of BMT, program of BMT, sense of family between boards and BMT member, cooperation between BMT and members. The Mean of each statements are, 4,41 for information access, 4,51 for promotion that is conducted by BMT, 4,38 for program of BMT, 4,51 sense of family between boards of BMT and members, and the last 4,59 for cooperation between boards BMT and members. The median value is 5,00 for promotion that is conducted by BMT, 
for sense of family between boards of BMT and members, and for cooperation between boards BMT and members. While median value is 4,00 for information access and for program of BMT. For the mode, promotion that is conduct by BMT, sense of family between boards of BMT and members, and for cooperation between boards BMT and members the value is 5 . While for information access and programs of BMT the mode value is 4. Social capital on networks aspect has the biggest value after the trust aspect.
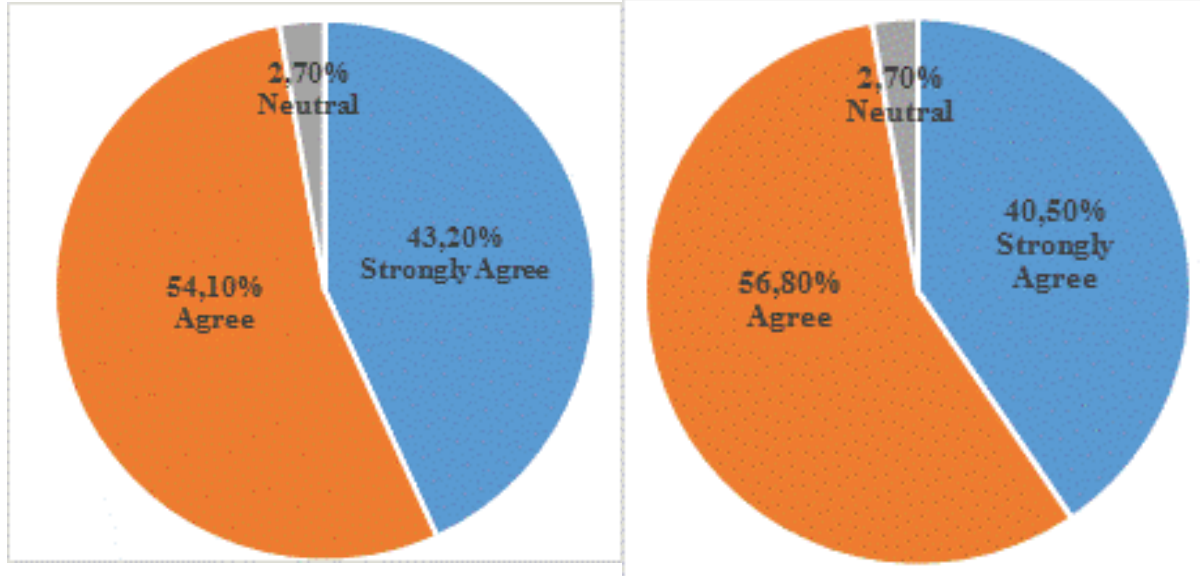

Figure 3.

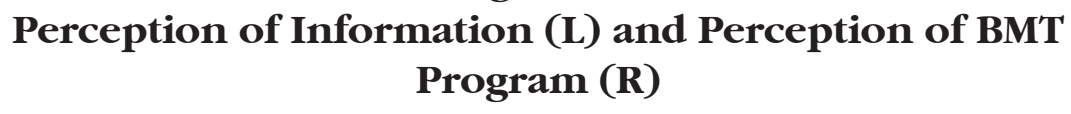

Based on figure above, there are 37 respondents replied the questionnaire. In social network aspect, first statement discussed the ease of information that the members can get. Majority of the respondents replied strongly agree ( 43.20 percent), followed by 54.10 percent respondents replied agree, and 2.70 percent respondent replied neutral. BMT officials is believed has given the easy access to the members to get information. So that members can ask anything related to BMT, and the officials will give a good explanation. "Yes we give easy access for member to get information. Most of members always ask about assets growth, SHU growth, and financial conditions. Officials always answer all the question, so members can feel free to ask everything related to BMT Kompak" 
(Nurmaslah, head of BMT Kompak, December 22, 2015). "BMT officials will give information to members if it necessary" (Abdul Latief, head of BMT Prima Artha, December 28, 2015).

Statement about participation of members in every program held by BMT, for about 40.50 percent respondents replied strongly agree, 56.80 percent respondents replied agree, and 2,70 percent respondents replied neutral. BMT officials explained that every event that is held by BMT aims to build social networks with all members
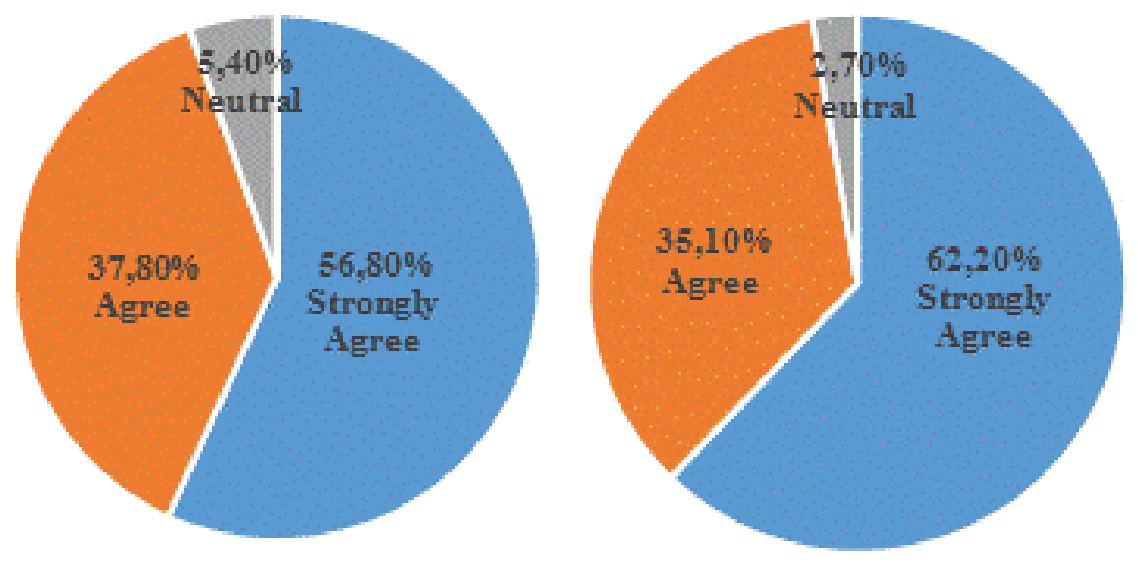

Figure 4.

Perception of Family Sense (L) and Perception of Cooperation (R)

Statement about sense of family between BMT and customers as many as $\mathbf{5 6 . 8 0}$ percent respondents replied strongly agree, 37.80 percent respondents replied agreed, and 5.40 percent respondents replied neutral. Most of board $\mathrm{f}$ have strong sense of family with customers. "BMT has a good sense of family with all members. Because our BMT based on community" (Nurmaslah, chief of BMT Kompak, December 22, 2015).

Statement about cooperation between BMT and customers, most of respondents replied strongly agree (62.20 percent 
respondents), followed by 35.10 percent respondents replied agree, and 2.70 percent respondents replied neutral. It can be conclude that among BMT and members they have good cooperation. Here is some interview with several head of BMT. "Yes we have good cooperation with all members, we provide financing to start their business" (Nurmaslah, head of BMT Kompak, December 22, 2015). "Of course we have good cooperation with members" (Agus Susanto, head of BMT Mitra Lohjinawi, Decemebr 23, 2015).

Because of frequents interaction between BMT boards and members, it developed and build a social network among them. According to Postelnicu (2012), the research conclude that the connections (or ties) among individuals allow them to collect the soft information available in their network in order to circumvent information asymmetries. Larance (1998) has stated that Grameen Bank enabled women to invest in community life through regular and frequent interactions and develop networking skills by building new network reaching beyond their familial networks.

\section{Norms Variable}

Based on statistical test, the most number found in mode value of norms variable are 5. Means respondents replied strongly agree in the statement in questionnaire. It can be conclude that boards BMT have done social capital aspect of norms in BMT.

Table 6.

\section{Statistics Test of Norms Variable}

\begin{tabular}{lrrrrr}
\hline & Condition & $\begin{array}{c}\text { Islamic } \\
\text { Value }\end{array}$ & $\begin{array}{c}\text { Religion } \\
\text { Value }\end{array}$ & $\begin{array}{c}\text { Culture } \\
\text { Value }\end{array}$ & Polite \\
\hline N Valid & 37 & 37 & 37 & 37 & 37 \\
Missing & 0 & 0 & 0 & 0 & 0 \\
Mean & 4,35 & 4,59 & 4,49 & 4,05 & 4,62 \\
Median & 4,00 & 5,00 & 5,00 & 4,00 & 5,00 \\
Mode & 4 & 5 & 5 & 4 & 5 \\
\hline \multicolumn{5}{c}{ Sources: primary data, 2015 }
\end{tabular}


There are 5 statements, i.e. requirements for new members, Islamic value applied by BMT, religion value applied by BMT, culture value applied by BMT, and politeness of BMT officials. Mean of each statements are, 4,35 for requirements for new members, 4,59 for Islamic value apply by BMT, 4,49 for religion value apply by BMT, 4,05 for culture value apply by BMT, and the last 4,62 for politeness of boards BMT. The median value is 5,00 for Islamic value apply by BMT, religion value apply by BMT, and for politeness of boards BMT. While median value is 4,00 for requirements for new members and culture value applied by BMT. For Islamic value apply by BMT, religion value applied by BMT, and politeness of BMT official the mode value is 5 . While for requirements for new members and culture value applied by BMT mode value is 4 . Social aspect on norms aspect has the lowest value compare to trust and social networks.

To prove as an Islamic Financial Institution, BMT always apply the religion and Islamic value. According to BMT officials, the initial goal of establishment BMT is to eliminate the "loan shark". Because the loan shark always used interest in every transaction and interest is prohibited in Islam.
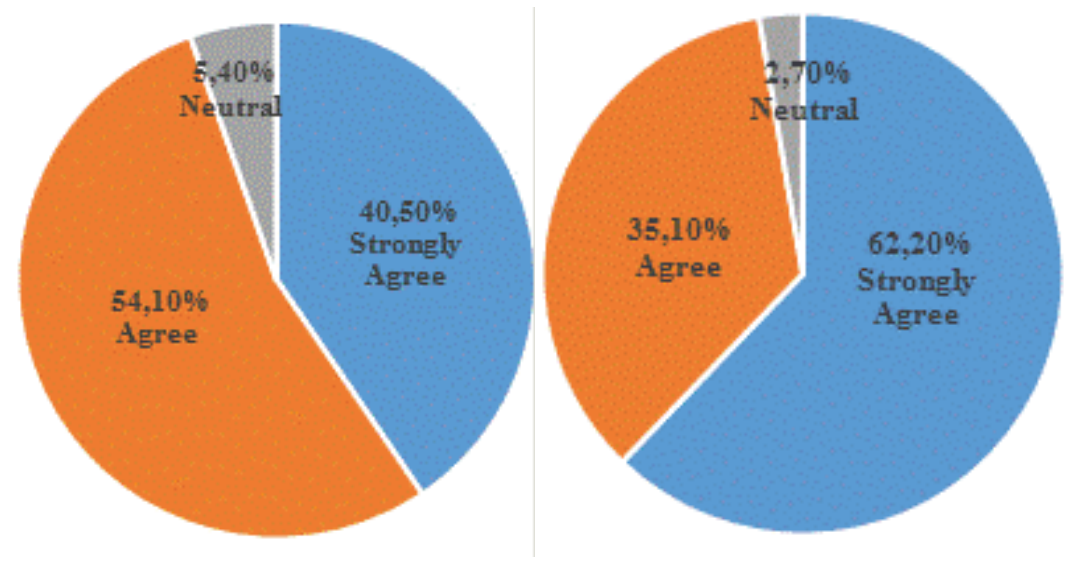

Figure 5.

Perception of Requirements (L) and Perception of Islamic Value (R)

Based on figure above, on first statement about requirements 
set by BMT for about 40.50 percent respondents replied strongly agree, 54.10 percent respondents replied agree, while 5.40 percent respondents replied neutral. Majority respondents agree that BMT set easy requirements for new members who want to join BMT. "BMT set easy requirements for members. Such as, financing used saving guarantee, fast process, installment directly taken by the officialsevery day, and SHU is shared every year" (Nurmaslah, head of BMT Kompak, December 22, 2015).

Statement about Islamic value which runs by BMT, for about 62.20 percent of respondents replied strongly agree, 35.10 percentrespondents replied agree, and 2.70 percent respondent replied neutral. As an Islamic financial institution, BMT always run each activity based on Islamic value. "As an Islamic financial institution, we applied Islamic value as our based on transaction. The aim of establishment BMT is to eliminate the loan shark from the market. So there is no usury or interest, but we used profit and loss sharing" (Agus Susanto, head of BMT Mitra Lohjinawi, December 23, 2015). "The Islamic value that must applied in BMT is change the usury system to profit and loss sharing system" (Dedi Heri Sutendi, head of BMT Elbumi 373, December 28, 2015).

According to research conduct by Dowla (2006), the result is the creation of social capital (horizontal and vertical networks) establishes a new norm to solve the collective action problems of poor people's access to capital. That would be important for sustainability of these institutions.

Civil social capital includes shared values and norms, membership in informal networks and associations that make individuals to cooperate with a view to achieving their common goals. And norms determine the quality and quantity of a society's social connections (Knack (1999) in Tundui C, and H Tundui (2013).

A social norm is a rule of behavior that the members of a community follow and if everyone acts in accordance with the norm then it must be in everyone else's interest to also act according to the norm ((Dasgupta, in Göransson and Östergren, 2010). In accordance with Dasgupta, social capital on norms aspect that applied by BMT aims to follow the norms that applied in society, so 
the requirements that set by BMT can be accepted by society. Also as an Islamic financial institution, BMT should follow the Islamic value and religion value. So every activity in BMT is based on Islamic value and religion value. Politeness also indicator of norms, so either BMT officials or members should keep their politeness.

\section{Conclucion}

This study starts by descriptive statistics analysis. According to the analysis and the explanation in the previous chapters, there are several conclusions such as: 1) BMT has succeed a good record on doing the social capital. Social capital in this research consist of 3 aspects, i.e. trust, social networks and norms. Each variable cannot be separated from one to another. Because each variable influence each other. Trust is the basis of the establishment in social network of BMT. Sustainability of social capital aspect on social network that is conducted by BMT should be based on the norms that prevail in society. 2) The existence of social capital aspect of trust gives positive impact to the BMT and members as well. Because BMT has been trusted by the members, BMT can continue to develop and because of the trust, members can apply financing without material guarantee. Trust becomes the most social capital variables that are widely applied by BMT. 3) The existence of social capital aspect of social networks gives benefits and positive influences to the BMT and members. Social network establishes good cooperation between BMT and members. Furthermore, because the locations of BMT are mostly located in one area, and have the same visions and missions. 4) The existence of social capital aspect of norms gives benefits and positive impact to BMT and members. Islamic value and religion value change the perspective of its members. Before joining BMT, they always applied financing to "loan shark" that used interest system. Now, they join BMT and applied the financing using the profit-loss sharing system. BMT can also eliminate the number of loan shark.

Regarding to this research, there are several recommendations as the implementation from the research findings: 1) BMT should try 
to increase the value of social networks aspect and norms aspects. So both of the aspect can have the high value like trust aspect. 2) For the further researchers need to use different variables which are relevant to social capital in another BMT along with adding the time research period, and use different methodology.

\section{References}

Basargekar, Prema. 2010. Measuring Effectiveness of Social Capital in Microfinance: A Case Study of Urban Microfinance Programme in India, International Journal of Social Inquiry Volume 3 Number 22010 pp. 25-43.

Basuki, A., T. 2015. Regressi dalam Penelitian Ekonomi dan Bisnis, edisi 1, Yogyakarta: Danisa Media.

Basuki, A., T., and Yuliadi, Imamudin. 2014. Elektronik Data Prosesing (SPSS 15 dan EVIEWS 7), Yogyakarta: Danisa Media.

Bowles, S. And Gintis, H. Social capital and community governance, Paper for a symposium submitted to the Economic Journal. http://wwwunix. oit.umass.edu/bowles.

Dowla, A. 2006. In credit we trust: buiding social capital by Grameen Bank in Bangladesh, Journal of Socio-Economics 35, page 102-122.

Fitriasari, Yanisa, 2015. Analysis of Micro, Small, and Medium Enterprises Perception towards Social Capital of BMT (Baitul Maal Wa Tamwil), Yogyakarta: Muhammadiyah University of Yogyakarta.

Goransson, K., and Ostergen, A. 2010. Is Trust a Necessity? A Case Study of Group Lending within Microfinance in the Mbarara District, Uganda, Sweden: Nationalekonomiska Institutionen Vid Lunds Universitet.

Hossain, D.M. 2013. Social Capital and Microfinance: The Case of Grameen Bank, Bangladesh, Middle East Journal of Business- Volume 8, Bangladesh: University of Dhaka. 
Kanak, S., and Iiguni, Y. 2007. Microfinance Programs and Social Capital formation: The Present Scenario in a Rural Village of Bangladesh. The International Journal of Applied Economics and Finance, 2, page: 97 - 104.

Larance, L. 1998. Building Social capital from the Center: A Village Level Investigation of Bangladesh, Bangladesh: Grameen Bank.

Neilsen, A.M.D. 2012. The Supposed Connection between Group Microfinance and Social Capital: A Case Study of the Peruvian Microfinance Market and Social Capital Development, Copenhagen Business School.

Postelnicu, L. 2012. Social Capital and Repayment Performance of Group Lending in Microfinance", CEB Working Paper No 12/032, Belgium: Universite Libre de Bruxelles.

Prasetyo, B., and Jannah, L. M. 2006. Metode Penelitian Kuantitatif. Jakarta: PT Raja Grafindo Persada

Putnam, R. D. 2002. Democracies in Flux: The Evolution of Social Capital in Contemporary Society. New York: Oxford University Press, Inc.

Reed, K. K., Srinivasan, N. \& Doty, D. H. 2009. Adapting Human and Social Capital to Impact Performance: Some Empirical Findings from the U.S. Personal Banking Sector" Journal of Managerial Issues, 21(1), page:36-57.

Ridwan, M. 2005. Manajemen Baitul Maal Wa Tamwil (BMT), Yogyakarta: UII press.

Sholahuddin, M. 2006. Lembaga Ekonomi Dan Keuangan Islam, Surakarta: Muhammadiyah University Press.

Supardi, 2015. Identifikasi Modal Sosial Pada Sistem Pembiayaan Tanpa Agunan (Studi pada Koperasi Pandawa Kecamatan Sukun - Kota Malang). 
Tundui, C and Tundui, H 2013. An Empirical Analysis of Social Capital and Enterprise Performance in Tanzania: The Case of Women Owned Businesses", International Journal of Developing Societies Vol. 2, No. 1, page 50-60. 